\title{
Measuring How Destination Image and Perceive Value Affect Customers' Satisfaction for Ecotourism
}

\section{Putu Gede Iwan Trisna Jaya*}

${ }^{1}$ Universitas Pendidikan Nasional

\section{A R T I C L E I N F O}

Article history:

Received 19 February 2018

Received in revised form

6 Maret 2018

Accepted 12 April 2018

Available online 25 May 2018

Keywords:

Destination Image, Perceive

Value, Customer

Satisfaction, Ecotourism

\begin{abstract}
A B S T R A C T
This study purpose is to determine the effect of destination image and perceived value on the satisfaction's level of the tourists who visit ecotourism attractions. There are two studies conducted in this research, the first is to validate the effect of destination image to the customers' satisfaction level and also to see the dominant effect of each indicator from the destination image to Customer Satisfaction level. Subsequent study validates the effect of Perceived Value on the customers' satisfaction level as well as to see the dominant indicator of Perceived Value on the customers' satisfaction levels. The study population is the foreign tourists who visited Taman Ayun Pura Mengwi Badung tourist object of Bali. The samples size is set at 65 people. Respondents were selected based on convenience sampling technique from the tourists who already know that Taman Ayun Temple is an ecotourism attraction and received appreciation as world cultural heritage. The data is processed and analysed using SEM through PLS software. The results show that Destination Image and Perceived Value have a positive and significant effect on the Customers' Satisfaction. Perceived Value has a higher correlation coefficient value when it is compared to the Destination Image on the Customers' Satisfaction. This indicates that the managers of tourist object and travel should pay attention on the price paid by the tourists with acceptable or perceived benefits. Other indicators in Perceived Value that should be the evaluation's material is Functional Value and Emotional Value. This indicates that tourists who visit the tourist object pay attention to the service standard received and the pleasure feelings they obtained when they are traveling can increase the tourists' satisfaction.
\end{abstract}

\footnotetext{
* Corresponding author.

E-mail addresses: iwan.trisna@gmail.com (I Putu Gede Iwan Trisna Jaya)
} 


\section{Introduction}

The 36th annual session of the United Nations Educational, Scientific and Cultural Organization (UNESCO) in 2012 in Russia has decided that Taman Ayun Temple and Subak irrigation system is a world cultural heritage unit. Before it is known as one of the world's tourist destinations, Taman Ayun Temple is a sacred area and as an estuary dam during the dry season for 12 irrigations in the drainage basin of Pakerisan, Gianyar and irrigation in Catur Angga Batukaru Tabanan.

Through the award, Pura Taman Ayun is a tourist destination with socio-economic and religious representation in the form of cultural landscape complemented by irrigation system as Tri Hita Karana philosophy manifestation in Bali. This award emphasizes more on the concept of destination image as a tourism of cultural, ecotourism and religion owned by Pura Taman Ayun.

Through a survey of which the subject is foreign tourists visiting the tourist object of Taman Ayun, it is obtained that $70 \%$ of the tourists know the information through the internet and tour travel that Taman Ayun is one of the world cultural heritages. While the other $30 \%$ only know the information at the time of visiting. Williams \& Buswell, (2003) mention through the perspective of the consumption process, that the behaviour of tourists in doing the purchase is divided into three stages: pre-consumption, during the consumption and after visiting.

Overall, the tourists' consumption behaviour is an overall experience including pre-visit decision making, on-site experience, experience evaluation and post-visit behaviour. Lee et al. (2005) argue that Destination Image has two essential behaviour roles, those are affecting the decision-making process of the destination choice and conditioning the behaviour after the decision making as well as the decisions when conducting the on-site experience, evaluation (satisfaction) and future behavioural intentions (intention to return and to recommend the place). Research related to the effect of an image on consumers' behaviour especially on the consumers' loyalty has been done many times (Andreassen and Lindestad, 1998).

From the various studies that have been done, Destination Image has generally accepted to affect the tourists' behaviour (Lee \& Lee, 2005). Fakeye and Crompton (1991) mention that Destination Image is a person's mental picture of knowledge (belief), feelings and overall perceptions about a particular destination which is in this case is tourist destination.

In the literature, prior research related to the effect of destination image on the behaviour after the decision-making is often ignored. Bigne et al. (2001) in their research find that the effect of destination images on behaviour after decision-making is represented in on-site experience. In the on-site experience, the trip quality is perceived as a comparison between the expectations and the actual performance perceived by the visitors.

Furthermore, Brady \& Hult (2000) mention that the tourists' behaviour including their purpose in visiting and evaluation after the visit as well as the future behavioural intention. The next evaluation consists of the trip experience or the perceived trip quality obtained during visiting the destination, the perceived value and overall satisfaction, while the future behavioural intentions include the intention to return and the devotion to recommend.

Research with a focus on the relationship between the quality, satisfaction and behavioural intentions has been widely conducted. Lee et al. (2005) argues that in the marketing perspective, travellers who have chosen and had their preferred destination image tend to experience a pleasant onsite experience that ultimately has a positive quality of the perceived trip which then results in a better customers' satisfaction and behavioural attention levels.

In recent years, perceived value has received serious attention as an object of concern by researchers in tourism (Morais, \& Norman, 2001). Most studies use satisfaction measurement along with the perceived value $(\mathrm{Oh}, 2000)$, and the perceived value is the moderating variables between service quality and customers' satisfaction (Caruana, Money, \& Berthon, 2000). Zeithaml (1988) attributes perceived value to the profit received at the price paid.

According to him, such thing is the basic concept of quality and satisfaction. Empirical study also found that the positive effects of perceived value will also be felt on the tourists' behaviour as well as their future behavioural intentions. It can be concluded that the destination image and perceive value is good predictors of satisfaction level (Petrick, 2004).

Through understanding the relationship between the destination image and the perceive value on the satisfaction, the tourism managers will understand how to figure out an attractive image and increase the marketing efforts to improve the resource management. Therefore, this study has two main objectives. First, this study tries to create an integrated model of the tourists' consumption process by inserting the variables of destination image and perceived value on the tourists' satisfaction. Second, testing the relationship between the destination image and the perceive value with the customers' satisfaction level. 
Thus, the problem formulations rose in this research include H1: the more famous the destination image, then it will have a positive and significant effect on the tourists' satisfaction level and H2: the higher the perceived value owned, then it has a positive and significant effect on the customers' satisfaction level.

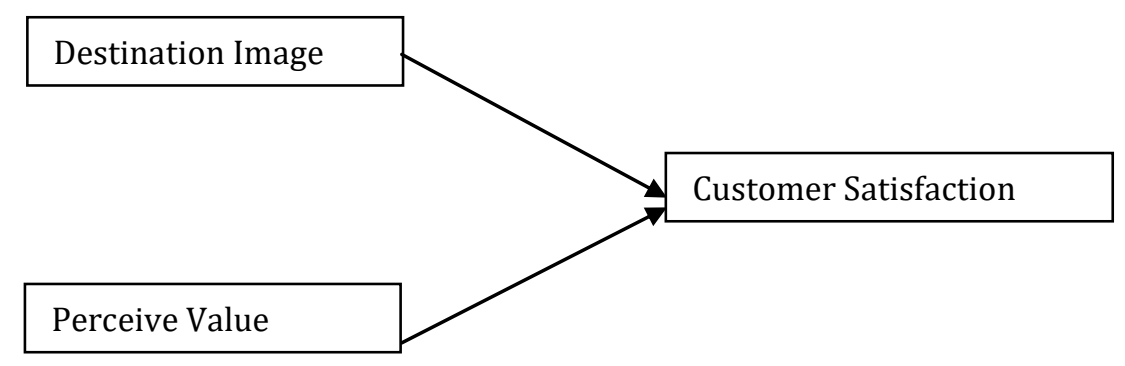

\section{Method}

In a research related to tourism marketing, understanding the determinants of tourist satisfaction has been considered as an important variable in the overall management level (Darnell and Johnson, 2001). Previous study (Chi and Qu, 2008) shows that destination images affect the tourists in the process of choosing the destinations, subsequent evaluations of their travel and future intentions. Destination image facilitates positive effect on the perceived quality, satisfaction and behavioural intentions (Bigne et al., 2001).

The population in this study is the tourists who come to the ecotourism attractions of Pura Taman Ayun by taking the samples of the foreign tourists who like the ecotourism attractions. For this study, among 100 distributed questioners, only 65 respondents that can be used. The sampling technique used is convenience sampling method.

According to Malhotra (2004), based on its characteristics, this research used qualitative and quantitative data. Meanwhile, based on the data source used, this research uses primary and secondary data. Ghozali (2001) mentions in management research that research variables usually are defined as latent variable (Constructor / factor) which is a variable that is directly measured but built through observed dimensions or indicators.

Indicator or dimension is usually observed by using questionnaire that aims to know the opinions of the respondents about Destination Image, Perceive Value and Customer Satisfaction. Each variable is measured through observed indicators through a questionnaire using a Linkert scale. After conducting a preliminary study of 30 samples of Foreign Tourist, 14 indicators that have the highest validity and reliability were identified: The variable of Destination Image consists of 5 question indicators The variable of Perceived Value consists of 3 question indicators The variable of Customer Satisfaction consists of four dimensions with 6 question indicators.

The data is collected through questionnaire distribution using Linkert scale of $1-5$ and convenience sampling technique, in which respondents are chosen based on criteria of liking Pura Taman Ayun Temple as ecotourism tourism object 3.5 Data Analysis Techniques This research uses SEM analysis technique (Structural Equation Modelling). According to Santoso (2012), SEM is a multivariate statistical technique which is a combination of factor and regression analysis (correlation) that aims to examine the relationships between variables exist in a model, whether it is between the indicator and the construct, or between the constructs. According to Ferdinand in Uttami (2012), research using SEM method (structural equation model) is based on the assessment on the interdependence relationship which is divided into seven steps or stages modelling, those are: (1) The development of theory-based model, (2) The preparation of path diagram (3) Constructing the structural equation (4) Selecting the input matrix and model/estimation technique (5) Assessing the possibility of problem identification (6) The evaluation of Goodness of Fit criteria and (7) The interpretation and modification of data.

\section{Result and Discussion}

Reliability testing aims to measure the reliability of the measuring tool or in other words whether the measuring tool is consistent if it is used to measure the same object more than twice. An instrument is considered as reliable if it is used several times to measure the same object but still produce the same data Sugiyono (2010). In other words, measurement which has high reliability is capable in delivering reliable results. In testing the reliability level, it usually uses a reliable variable or variable which is present when 
the Cronbach Alpha value is greater than 0.60 . The validity test of the statement items for each construct in the questionnaire can be seen in Table 1.

Table 1. The Reliability Test Result of Variable Indicator of Destination Image, Perceived Value and Satisfaction

\begin{tabular}{ll}
\hline & Cronbach's Alpha \\
\cline { 1 - 2 } Destination Image & 0.941 \\
Perceived Value & 0.870 \\
Satisfaction & 0.889 \\
\hline
\end{tabular}

for the destination image (x1) construct in which all statement items show the correlation value between the items and the total construct score which is greater than 0.30 so that all items are valid, as table 4.2 below. Similarly, with the perceived value (x2) construct which shows that the whole correlation of the statement items with the total construct score indicates that it is greater than 0.30 which means that all items are valid. it is also the same as the construct of satisfaction (y) seen in table 2. that the whole correlation item statement with the total score of construct shows greater than 0.30 which means that all items are valid. Based on the reliability and validity test result of indicators and items of research statements, it can be concluded that all indicators and items meet the requirements to be reliable and valid.

Table 2. The Validity Test Result

\begin{tabular}{|c|c|c|}
\hline Construct & Indicators & Correlation \\
\hline \multirow{5}{*}{ Destination Image (X1) } & 1. X1.1 & .515 \\
\hline & 2. $\mathrm{X} 1.2$ & .566 \\
\hline & 3. X1.3 & .584 \\
\hline & 4. X1.4 & .576 \\
\hline & 5. X1.5 & .525 \\
\hline \multirow{3}{*}{ Perceive Valued (X2) } & 1. X2.1 & .511 \\
\hline & 2. X2.2 & .448 \\
\hline & 3. X2.3 & .576 \\
\hline \multirow{6}{*}{ Satisfaction (Y) } & 1. Y1.1 & .452 \\
\hline & 2. $\mathrm{Y} 1.2$ & .499 \\
\hline & 3. Y1.3 & .566 \\
\hline & 4. $\mathrm{Y} 1.4$ & .814 \\
\hline & 5. Y1.5 & .855 \\
\hline & 6. Y1.6 & .515 \\
\hline
\end{tabular}

The inferential analysis in this research is conducted by using structural equation modelling (SEM) model through the program of SmartPLS 3.0. The steps taken in the analysis process include: 1) the evaluation of the measurement model or outer model with the purpose is to know the relationship between the indicators that make up the latent variables, and 2) the evaluation of the structural model or inner model with the purpose is to know the relationship of the variables that make up the research model.

Since the indicators that form the latent variables in this study are reflexive, the evaluation of the measurement model / outer model to measure the validity and reliability of those indicators are a) convergent validity, b) discriminant validity, and c) composite reliability and Cronbach alpha.

Since the indicators that form the latent variables in this study are reflexive, the evaluation of the measurement model / outer model to determine the validity and reliability of those indicators are a) convergent validity, b) discriminant validity, and c) composite reliability and Cronbach alpha.

Convergent validity is a criterion in measuring the validity of reflexive indicators. This evaluation is conducted through examination of the outer loading coefficient of each indicator to its latent variable. An indicator is valid, if the outer loading coefficient is between $0.60-0.70$. However, to analyse the unclear 
theory, then the outer loading recommended is 0.50 is recommended (Lathan and Ghozali, 2012), as well as the significance at alpha level of 0.05 or t-statistic of 1.96 .

Table 3. Outer Loading Value of Model Estimation Result

\begin{tabular}{|c|c|c|c|c|c|}
\hline & $\begin{array}{l}\text { Original } \\
\text { Sample (0) }\end{array}$ & $\begin{array}{l}\text { Sample } \\
\text { Mean (M) }\end{array}$ & $\begin{array}{ll}\text { Standard } & \text { Deviation } \\
\text { (STDEV) } & \end{array}$ & $\begin{array}{l}\text { T } \quad \text { Statistics } \\
(\mid 0 / \text { STDEV } \mid)\end{array}$ & $\begin{array}{l}\mathrm{P} \\
\text { Value } \\
\mathrm{s}\end{array}$ \\
\hline $\begin{array}{l}\text { X1.1 <- Destination } \\
\text { Image }\end{array}$ & 0.872 & 0.858 & 0.047 & 18.582 & 0.000 \\
\hline $\begin{array}{l}\mathrm{X} 1.2<- \text { Destination } \\
\text { Image }\end{array}$ & 0.860 & 0.852 & 0.046 & 18.782 & 0.000 \\
\hline $\begin{array}{l}\mathrm{X} 1.3<- \text { Destination } \\
\text { Image }\end{array}$ & 0.943 & 0.942 & 0.016 & 59.765 & 0.000 \\
\hline $\begin{array}{l}\mathrm{X} 1.4<- \text { Destination } \\
\text { Image }\end{array}$ & 0.923 & 0.919 & 0.021 & 43.899 & 0.000 \\
\hline $\begin{array}{l}\mathrm{X} 1.5<- \text { Destination } \\
\text { Image }\end{array}$ & 0.901 & 0.902 & 0.026 & 34.376 & 0.000 \\
\hline $\begin{array}{l}\text { X2.1 <- Perceived } \\
\text { Value }\end{array}$ & 0.912 & 0.908 & 0.021 & 43.174 & 0.000 \\
\hline $\begin{array}{l}\text { X2.2<- Perceived } \\
\text { Value }\end{array}$ & 0.872 & 0.864 & 0.040 & 21.810 & 0.000 \\
\hline $\begin{array}{l}\text { X2.3<- Perceived } \\
\text { Value }\end{array}$ & 0.889 & 0.881 & 0.025 & 35.031 & 0.000 \\
\hline $\begin{array}{l}\text { Y1.1 <- } \\
\text { Satisfaction }\end{array}$ & 0.806 & 0.799 & 0.037 & 21.625 & 0.000 \\
\hline $\begin{array}{l}\text { Y1.2 } \\
\text { Satisfaction }\end{array}$ & 0.837 & 0.838 & 0.028 & 29.653 & 0.000 \\
\hline $\begin{array}{l}\text { Y1.3 } \\
\text { Satisfaction }\end{array}$ & 0.877 & 0.874 & 0.033 & 26.649 & 0.000 \\
\hline $\begin{array}{l}\text { Y1.4 } \\
\text { Satisfaction }\end{array}$ & 0.818 & 0.803 & 0.079 & 10.390 & 0.000 \\
\hline $\begin{array}{l}\text { Y1.5 } \\
\text { Satisfaction }\end{array}$ & 0.818 & 0.801 & 0.076 & 10.803 & 0.000 \\
\hline
\end{tabular}

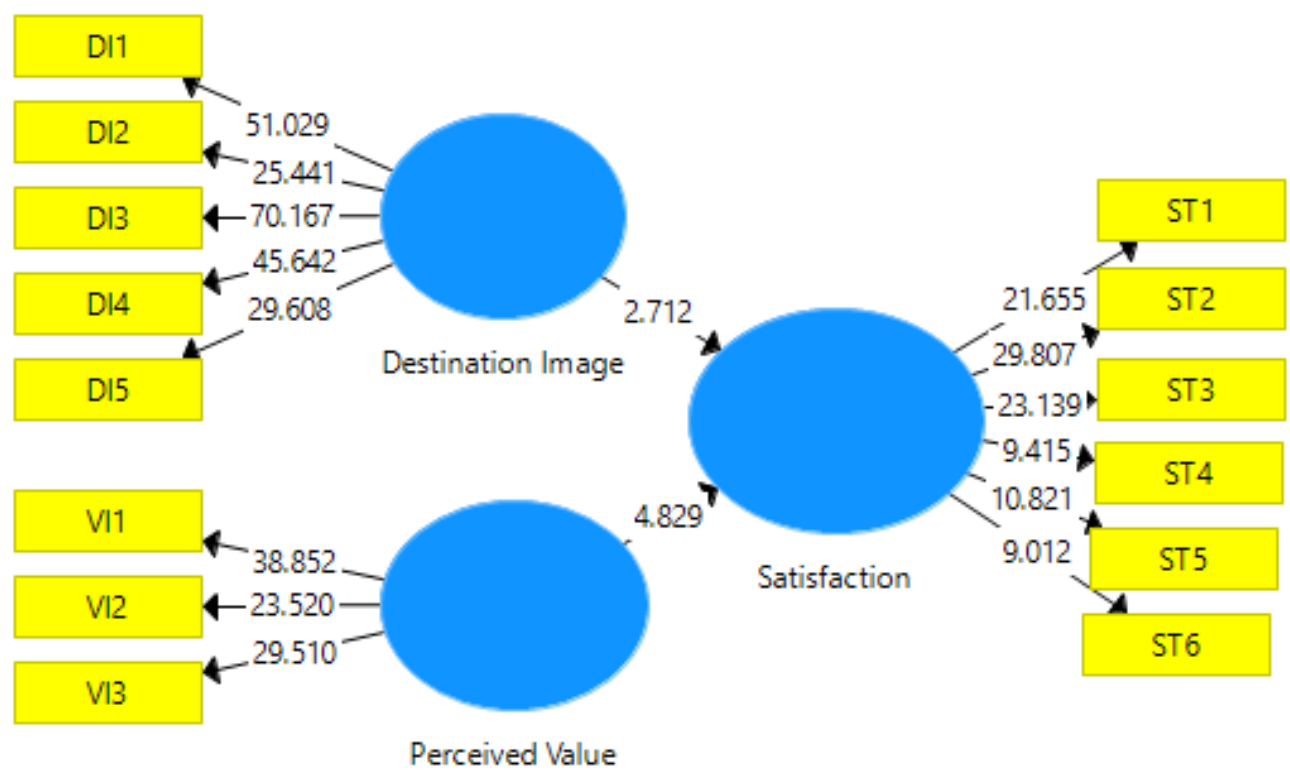

Figure 1. Outer Loading and Coefficient Path 


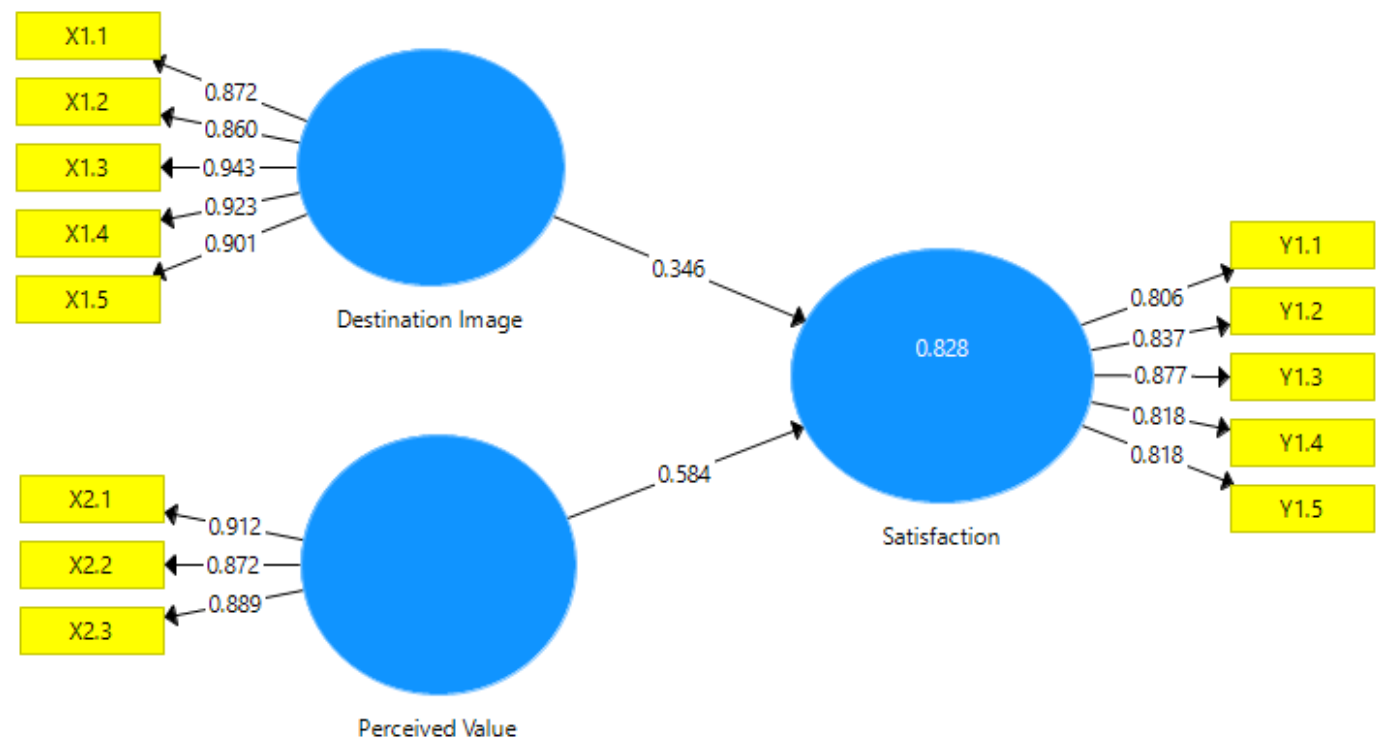

Figure 2. Boothstrapping Model

The validity measurements of the indicators that form the latent variables can also be done through discriminant validity. Discriminant validity can be done by comparing the AVE Root coefficient ( $\sqrt{A V E}$ or Square root Average Variance Extracted) of each variable to the correlation value between the variables in the model. A variable is valid if the AVE root ( $\sqrt{A V E}$ or Square root Average Variance Extracted) is greater than the correlation value between the variables in the research model (Lathan and Ghozali, 2012), and AVE is greater than 0.50 .

Table 4. Discriminant Validity

\begin{tabular}{lll}
\hline & Average Variance Extracted (AVE) & $(\sqrt{\mathrm{AVE}})$ \\
\hline Destination Image & 0,811 & 0.900 \\
Perceived Value & 0,794 & 0.891 \\
Satisfaction & 0,692 & 0.831 \\
\hline
\end{tabular}

A measurement is reliable if the composite reliability and cronbach alpha has a greater value than 0.70. Composite reliability and Cronbach alpha is a measure of reliability between the indicator blocks in the research model.

Table 5. Composite Reliability dan Cronbach Alpha Test

\begin{tabular}{lll}
\hline & Cronbach's Alpha & $\begin{array}{l}\text { Composite } \\
\text { Reliability }\end{array}$ \\
\hline Emotional Response & 0.941 & 0.955 \\
Impulse Buying & 0.870 & 0.920 \\
Store Atmosphere & 0.889 & 0.918 \\
\hline
\end{tabular}

Table 5 shows that the value of composite reliability and Cronbach Alpha of all constructs have a value greater than 0.70 , therefore it fulfils the requirement of being reliable based on composite reliability criteria. The Evaluation of Structural Model/Inner Model is a measurement to evaluate the model's accuracy level in the overall study which is formed through several variables along with its indicators. In 
the evaluation of this structural model, several approaches will be done include: a) R-Square (R2), b) QSquare Predictive Relevance (Q2), and c) Goodness of Fit (GoF).

R-Square (R2) can indicate the strength and weakness of the effect caused by the dependent variable on the independent variable. R-Square (R2) can also indicate the strength and weakness of a research model. According to Chin (Lathan and Ghozali, 2012: 85), the R-Square (R2) of 0.67 is considered to be a strong model, while R-Square (R2) of 0.33 is considered to be moderate, and R-Square (R2) of 0, 19 is considered to be a weak model.

Based on the criteria of Chin (Lathan and Ghozali, 2012), the model includes strong model criteria which means that the variation of Destination image and Perceived Value is able to explain Satisfaction of 82.3 percent, while the remaining 17.7 percent is explained by the variations of other variables.

Table 6. The Evaluation of Inner Structural Model

\begin{tabular}{ll}
\hline & R Square \\
\hline Impulse Buying & 0.823 \\
\hline
\end{tabular}

Path Analysis and Hypothesis Testing expect that Ho is rejected or the sig. value is $<0.05$ (or the $t$ statistic value $>1.96$ if is tested by using significant level of 0.05 .

Table 7. Path Analysis and Statistical Testing

\begin{tabular}{lllllll}
\hline & & $\begin{array}{l}\text { Original } \\
\text { Sample (0) }\end{array}$ & $\begin{array}{l}\text { Sample } \\
\text { Mean (M) }\end{array}$ & $\begin{array}{l}\text { Standard Deviation } \\
(\mathrm{STDEV})\end{array}$ & $\begin{array}{l}\mathrm{T} \text { Statistics } \\
(\mid \mathrm{O} / \mathrm{STDEV})\end{array}$ & $\begin{array}{l}\mathrm{P} \\
\text { Values }\end{array}$ \\
\hline $\begin{array}{l}\text { Destination Image } \\
\text { Satisfaction }\end{array}$ & $->$ & 0.346 & 0.342 & 0.139 & 2.486 & 0.016 \\
$\begin{array}{l}\text { Perceived Value } \\
\text { Satisfaction }\end{array}$ & $->0.584$ & 0.587 & 0.135 & 4.336 & 0.000 \\
\hline
\end{tabular}

Table 7 shows that all relationships between the variables show significance which means that all research objectives have been answered. The perception of Destination image through five indicators has a significant effect through probability value of 0.016 which is smaller than 0.05 and t count of 2.486 which is higher than the statistical value of 1.96 to the Satisfaction variable which has a positive direction with the correlation coefficient of 0.346 . This indicates that the better the reputation of a tourist destination area, the better the customer satisfaction level is. The result of this research is in accordance with a research conducted by Chen and Tsai (2016).

Still in the same table, Perceived Value also has a positive and significant influence on satisfaction with a correlation coefficient of 0.504 . According to a research conducted by Han in 2017, the customer satisfaction level will be stronger if it is supported by economic value, functional value and emotional value.

The practical implication of this research proves that to increase the tourist satisfaction level related to a certain tourism object, it is suggested that the management of the tourist destination should try to build a positive image of the tourism object. The positive destination of this research is formed from the indicators of the many interesting cultural attractions, the infrastructure owned, the pleasant environment, including the pollution-free environment, and the exotic imagery of the tourist destination. From the result of the correlation coefficient value owned by each indicator, it is seen that the tourism object of Pura Taman Ayun which is included in ecotourism and received appreciation from UNESCO shows its dominance on the pleasant environment indicator including the indicator with pollution-free environment as the dominant indicator to form the positive destination image. The economic value indicator has correlation coefficient value which is more dominant when it is compared to the functional and emotional value, meaning that foreign tourists who visit ecotourism object of Taman Ayun consider that the value of money has been paid is proportional to the benefits obtained.

\section{Conclusion and Recommendations}

The result shows that Destination image and Perceived value give a positive and significant effect on the customer satisfaction level. Pura Taman Ayun is a tourist destination with ecotourism market segmentation which is completed with the appreciation from UNESCO related to world cultural heritage. It appears that the Destination Image variable with its two indicators is a pleasant environmental indicator and pollution-free environment indicator indicate that as ecotourism object, the image to be established 
has been successfully perceived by tourists. The Perceived Value variable shows that the economic value indicator with the value of money is more dominant when it is compared to the other two indicators. This shows that the tourists feel the benefits of traveling and are satisfied with the amount of money they has been paid.

In accordance with the results of this research, Destination Image is a form of image that must be built positively to increase the tourists' satisfaction. The managers of the tourist destinations should pay attention to a pleasant environment and pollution-free, especially if the image built is ecotourism tourist destination. It is not only these two indicators, but according to the results, the tourism site management should also pay attention to interesting tourist attractions that can invite tourists to come to visit besides that a good tourism support infrastructure should also be equipped and the whole package makes the tourist object becomes unique and exotic in the eyes of the tourists. To improve the tourists' satisfaction level and provide a positive experience based on the results of research, then the manager should consider some indicators related to perceived value in the form of economic value for tourists to consider that the money they spent is according to the facilities and benefits obtained. Besides, the functional value aspect in the form of standard quality indicators of service to tourists during the visit in the tourist object also must be maintained so that the final variable of perceived value that is emotional value in the form of happy tourist indicator during the visit in tourist objects can be felt.

\section{References}

Baloglu, S., \& McCleary, K. W. (1999). A model of destination image formation. Annals of Tourism Research, 26(4), 868-897.

Bigne, J., Sanchez, M., \& Sanchez, J. (2001). Tourism image, evaluation variables and after urchase behavior: Inter-relationships. Tourism Management, 22(6), 607-616. Caruana, A., Money, A. H., \& Berthon, P. R. (2000).

Service quality and satisfaction: The moderating role of value. European Journal of Marketing, 34(11/12), 1338-1352. E.

Cruz Ruiz, G. Bermúdez González, D. Tous Zamora, Tourism \& Management Studies, 14(1), 2018, 58-68 Fakeye, P., \& Crompton, J. (1991).

Image differences between prospective, first-time, and repeat visitors to the lower Rio Grande valley. Journal of Travel Research, 30(2), 10-16.

Fornell, C., 1992. A national customer satisfaction barometer: the Swedish experience. Journal of Marketing 55, 1-21.

Gronroos, C., 1997. Value-driven relational marketing: from products to resources and competencies. Journal of Marketing Management 13, 407-419.

J. JOSEPH CRONIN, JR.MICHAEL K. BRADY, G. TOMAS M. HULT. (2000).Assessing the Effects of Quality, Value, and Customer Satisfaction on Consumer Behavioral Intentions in Service Environments. Journal of Retailing, Volume 76(2) pp. 193-218, ISSN: 0022-4359

Kyung-Hee Kim \& Duk-Byeong Park, 2016. Relationships Among Perceived Value, Satisfaction, and Loyalty: Community-Based Ecotourism in Korea

Lee, C., Lee, Y., \& Lee, B. (2005). Korea's destination image formed by the 2002 world cup. Annals of Tourism Research, 32(4), 839-858.

Lovelock, C.H., 2000. Service Marketing, fourth ed. Prentice Hall International.

Oh, H., 2000. Diner's perceptions of quality, value and satisfaction. Cornell Hotel and Restaurant Administration Quality 41 (3), 58-66.

Petrick, J. F. (2004). The roles of quality, perceived value and satisfaction in predicting cruise passengers' behavioral intentions. Journal of Travel Research, 42(4), 397-407. 
Williams, C., \& Buswell, J. (2003). Service quality in leisure and tourism. UK: CABI Publishing.

Zeithaml, V. A. (1988). Consumer perceptions of price, quality and value: A means-end model and synthesis of evidence. Journal of Marketing, 52(July), 2-22.

Zeithaml, V.A., 1988. Consumer perceptions of price, quality and value: a means-end model and synthesis of evidence. Journal of Marketing 52 (July), 2-22. 